\title{
Adapting the Tuning Programme Profiles to the Needs of Russian Higher Education
}

\author{
Yevgeniya V. Karavayeva and Yelena N. Kovtun
}

\begin{abstract}
This article considers how TUNING-compatible programme profiles could be developed in the Russian Federation in the context of: on-going reform of the higher education; introduction of the new generation of Federal State Educational Standards (FSES); development of the new professional standards; implementation of a system of public accreditation of educational programmes; and a complex system of educational quality assessment.

It also analyses the results of monitoring of the effectiveness of FSES implementation in the system of Russian higher education by the Association of the Classical Universities of Russia (ACUR) that identified a number of problems in the area of programme design and implementation related to drawbacks within the current FSES.

Based on the experience gained during the implementation of the TUNING RUSSIA Project (2010-2013), this article demonstrates the usefulness of the TUNING basic principles and approaches and suggests the ways TUNING profile development methodology might be successfully adapted and applied for designing educational programmes in the course of the Russian higher education reform.

Creating TUNING-model degree profiles may be crucial to aid the Russian higher education institutions in the development of the new educational programs. Brief but all-encompassing formulation of the aims and outcomes and specific characteristics of an educational programme, listing competences and learning outcomes could permit higher education institutions to move from trying to comply with standards and requirements, which are sent from above but are foreign to the institutions themselves, to adopting the principle of transparency and designing better and more competitive degrees.
\end{abstract}

Keywords: Bologna process; higher education reform in Russia; TUNINGcompatible programme profiles.

\section{Introduction}

The methodology for design and implementation of educational programmes developed within the framework of the Tuning Educational Structures in Europe - the TUNING international project is gradually becoming the leading approach within the common European education space that is consistent with the Bologna Process principles. The major attractions 
of this methodology are the clarity of its basic principles (development of a suitable "meta-language" of international education), the clear and logical description of educational processes and its ability to account for and reconcile the educational models of different countries through advocating a common approach to defining aims, techniques and outcomes.

The core principles of the TUNING methodology and its most evident contribution towards enhancing education consists in bringing together competence-based education and transparent educational outcomes (making these comprehensible for all the stakeholders). Thus, higher education institutions are expected to formulate their educational goals in a succinct and precise way; employers are invited to select recent graduates as potential employees in a conscious and objective manner and to plan better their future professional development; while the students themselves are encouraged to become pro-active in terms of determining their educational needs and preparing for their desired employment.

The quintessence of this approach resides in the so called Profiles (specifications) of educational programmes. A perfect implementation of the TUNING philosophy, these contain an exhaustive description of educational aims and outcomes, which, in turn, locate each educational programme within the context of other programmes both within a country and internationally. The Profiles explain what each graduate will learn and how and at what level these elements will be taught (according to the international educational programmes' indexes, and to the national and international qualification frameworks). There is no doubt that such Profiles will be introduced in some manner by all the members of the Bologna Process. Yet, it is equally clear that each participant country needs to develop Profiles compatible with the existing national educational system and that in order to implement this practice certain country-specific obstacles will need to be overcome.

This article considers how TUNING-compatible programme Profiles could be developed within the Russian Federation framework of higher education.

\section{Historical Context}

Russian higher education degrees have traditionally provided a broad foundational (fundamental) rather than narrow practice-oriented professional training.

After the Soviet Union collapsed the Russian Federation introduced state educational standards (SESs) aimed at unification of the content of educational programs at all of the higher education institutions (HEIs). 
The first "generation" of the SESs was introduced in late 1990s and does not practically allow HEIs any freedom in designing educational programs. The second "generation" of the SESs introduced in 2000 allowed HEIs to suggest up to $20 \%$ of the educational program content. SESs-1 and SESs-2 set "minimal" requirements for the content of educational programs and determined a fixed list of mandatory disciplines (subjects) along with the number of teaching hours allocated for those disciplines.

Russia joined the Bologna Process in 2003 and a number of measures have been taken since then in order to ensure terminological, normative and content-related compatibility of the Russian educational model with European practice. The classification of areas and programmes of studies has been revised, new-generation educational standards have been developed, professional standards are being developed, a system of public accreditation of educational programmes and a complex system of educational quality assessment are being implemented.

The core principles of programme design and implementation reflected in the new normative and methodological documents have been informed by, among others, the TUNING approach. Thus, Federal State Educational Standards (FSES), incorporating the employers' opinions and approved in 2010-2011, speak of the competence approach, learning-outcome orientation as well as of calculating students' workload in credit units, and also mention the possibility of introducing a modular principle of curriculum design. ${ }^{1} \mathrm{New}$ standards do not set rigid requirements for the content of educational programs, therefore, providing HEIs with more freedom in designing educational programs.

During the last 2-3 years, Russian higher education institutions (HEIs) have (re)designed and implemented educational programmes following FSES guidelines.

\section{The Monitoring Project}

These new programmes are commonly referred to as core educational programmes (CEPs). In 2011-2012, the Association of the Classical Universities of Russia (ACUR), commissioned by the Ministry of Education and Science of the Russian Federation, has started monitoring the effectiveness of FSES implementation into the system of Russian higher education. This Monitoring project will continue in 2013 and is expected to focus on

${ }^{1}$ See more in: Baydenko V.I., Designing federal state educational standards of higher professional education: a pilot educational program. Moscow, 2007. 
analysing CEPs, among other things. ACUR experts are evaluating how well CEPs meet the requirements not only of FSES but also of the basic principles of the Bologna Process, including the major points of the TUNING methodology. ${ }^{2}$

The questionnaires administered within the Monitoring project to different categories of HEIs' employees have revealed a certain level of familiarity with the TUNING methodology. E.g., for the question "What was the priority method of determining additional competences to be developed by the CEP graduate?" $12.5 \%$ of respondents said that relevant TUNING subject-area-specific recommendations were taken into account. At the same time, 38.8\% responded positively when asked whether Tuning Educational Structures in Europe international project methodology had been used by their HEI for designing CEPs.

This relatively high level of familiarity is not surprising. Some Russian HEIs first used the TUNING methodology back in 2006-2007. The Higher School of Economics, the People's Friendship University of Russia and Tomsk State University were the pioneers. Within the framework of Tuning Educational Programmes in Russian HEIs TEMPUS project, these HEIs used the TUNING methodology to design Bachelor and Master programmes in European Studies and Applied Mathematics. In 2007-2008, another Tempus project - A Russian Tuning-ECTS based-model for the Implementation of the Bologna Process in Human Sciences (RHUSTE) was carried out. As an outcome, educational programmes in History and Culture Studies were developed for different levels. ${ }^{3}$ Finally, since 2010 a number of Russian HEIs have been working together in a new Tempus project: Tuning Russia. The project's aims and objectives are further discussed below.

However, it must be admitted that the assumed familiarity with TUNING methodology was disproved by the analysis of the CEPs' documentation by monitoring ACUR subject area experts. These experts had to conclude that while the competence and credit-based approach to CEP design was observed formally (thus, complying with FSES requirements), HEIs usually had a poor understanding of what this approach entailed and often did not observe the

${ }^{2}$ More details on monitoring project and on its interim results see in: - The experience of implementing federal state educational standards by professional education institutions of the Volga federal district (Saratov, 29-30 October 2012). Saratov: Saratov University Publishing House, 2012.

${ }^{3}$ Kovtun, Y.N., ed., Model of creating core educational programs in humanities based on TUNING-ECTS methodology for the implementation of the principles of Bologna process in Russia. History and Culturology. Chelyabinsk, 2008. 
sequence and logic of the TUNING step-by-step model for designing educational programmes. ${ }^{4}$

The Tuning model comprises the following steps:

- Confirm the existing social need for the programme and define the programme profile;

- Describe programme objectives and identify the key competences (generic and subject-specific) it should develop;

- Identify and formulate measurable learning outcomes that should demonstrate that the graduate has developed the competences;

- Design and describe the programme contents and structure (modules and credits);

- Check the correspondence among the programme structure, the learning outcomes and the key competences;

- Select approaches to teaching and learning as well as methods of assessment in line with the competences to be developed;

- Develop an evaluation and quality assessment system.

The monitoring experts checked whether the educational programme documentation of the Russian HEIs reflected the following:

- CEP mission statement - a general description of professional and personal qualities of a graduate, information on the areas of professional activity and on the economy sectors where the demand for such specialists is expected;

- Competences to be developed by the CEP graduate (primarily those in addition to the core competences already listed in FSES);

- Methodological support through teaching and learning techniques and a system of quality assurance to make sure students complete the CEP successfully (including materials and recommendations for continuous and interim evaluation);

- Requirements for the final state examination;

- Evidence of HEI's cooperation with employers in developing the CEP.

Special attention was paid to the mission statement because the task of comprehending and formulating the mission statement is key to the whole process of programme design. The aim is to define the graduate's profile in

${ }^{4}$ Results of the review of educational programs of Russian HEIs within the framework of the "Monitoring" project are described in: Kovtun, Y.N., Results of the review of the core educational programs of HEIs, developed in accordance with the FSES: analytical report for informational-methodological seminars for HEIs. Saratov: Saratov University Publishing House, 2012. 
accordance with the academic specialisation of the university and with the labour market requirements. This statement determines the competences to be developed and, therefore, the disciplines and internships that should build up the programme. ACUR experts assessed whether the future areas of the graduates' professional activity were formulated correctly and with due detail; whether the graduate's profile was specified; and whether the mission statement matched the labour market demands.

The majority of the monitoring experts had to conclude that CEPs analysed do no more than mechanically reproduce fragments of relevant sections of FSES and/or of Sample CEPs (SCEPs) designed by FSES authors. The experts observed: "None of CEPs examined pointed out how the graduate's qualifications match the regional/country-level labour market demands"; "Aims are normally formulated at a very abstract level and literally reproduce SCEPs' aims"; "Programme designers tried to follow FSES guidelines as much as possible and demonstrate their own initiative as little as possible"; "Missions in the majority of HEIs are formulated in an abstract way, without taking into account regional labour market characteristics and profile"; "CEP aim is formulated in very general terms"; "In the majority of CEPs the aim (mission) is formulated in an abstract manner and has no practical value, for example 'The aim (mission) of the present BA CEP is to equip students - future Bachelors - ... with common cultural, professional and subject-specific competences in accordance with the FSES requirements and SCEPs' recommendations' or 'BA CEP aims at developing students' personal qualities as well as common cultural (universal) and professional competences in accordance with FSES requirements"'.

The experts stated that such a formalistic approach to specifying educational aims leads to the absence of a coherent graduate's profile, resulting in both students and employers being unable to identify the specific features of a particular educational programme and to compare CEPs of various HEIs within one country, not to mention international programme comparison.

A similar formal approach was identified by the experts when analysing the competences graduates were expected to develop. In the majority of cases, programme designers simply copied the competence lists contained in FSES or SCEPs. Additional competences are very rarely added and do not contribute to the programme's specificity. There was also hardly any evidence that relevant employers were consulted in order to identify these additional competences. As a result, there was no clear link between the list of competences and the expected learning outcomes. Finally, this resulted in a lack of recommendations about ways to achieve the desired learning outcomes (in terms of disciplines, internships, continuous and interim evaluation, or even in terms of final evaluation procedures). 
Therefore, it is clear that when designing CEPs Russian HEIs pay insufficient attention to the first three steps of the TUNING model:

- Confirm the existing social need for the programme and define the programme profile;

- Describe programme objectives and identify the key competences (generic and subject-specific) it should develop;

- Identify and formulate measurable learning outcomes that should demonstrate that the graduate has developed the competences.

This inevitably detracted from the logic of CEP design, led to the absence of clearly stated aims and objectives of a CEP and to the question of labour market demands for the graduates of a specific profile being ignored. The curricula, then, did not match the competences listed, while the competences (despite occasional excessive level of detail) often did not sum up to a coherent and labour-market-tailored profile.

One could attribute these drawbacks to the fact that Russia is just making the first steps towards bringing its national educational space in line with the European one. Nonetheless, disregarding such problems might nullify the positive effect expected of the current Russian higher education reform initiatives. Indeed, if HEIs consider the current reform to be no more than another bureaucratic top-down campaign, the Russian higher education programmes can hardly aspire to ever become compatible and comparable with those of Europe.

On the other hand, not all the fault lies with Russian HEIs. Russian statutory documents, including the education law, are often vague or imprecise. Thus, the definition of a CEP in both On Education and On Higher and Post-University Professional Education laws ${ }^{5}$ goes as follows: "Core education programme of the higher professional education shall implement the federal state educational standard in accordance with the type of higher education institution, and educational needs and demands of students; it comprises curriculum, working programmes of subjects and disciplines (modules) and other materials that should ensure the quality of training, as well as plans for internships, an academic calendar and methodological materials that ensure the relevant teaching and learning techniques are employed". Thus, the description of the programme profile, the programme aims, the graduate's competence model or the desired learning outcomes are not featured among the compulsory CEP elements.

5 Article 9, p.6.2 of the Russian Federal Law of 10 July 1992 № 3266-I “On Education”; article 5 p.5 of the Federal Law of 22 August 1996 N 125-FZ "On higher and post-HEI professional education". 
It is true that the requirement to comply with the federal educational standards implies that all these elements should be present, since the FSES mention them. Still, the existing normative documents do not clearly state that a HEI must provide such information. The normative documents limit themselves to declaring that descriptions of major professional roles for which the bachelor student is prepared are to be defined by HEIs together with the student, academic staff and employer organisations.

In other words, the legislation does not encourage HEIs to actively seek programme specialisation, while HEIs, perhaps due, among other things, to their previous experience, are not eager to take the initiative. As one of ACUR experts involved in Monitoring observed, "The reasons seem to be administrative rather than psychological: It is often difficult to get the Rector's office to approve a document full of innovative approaches".

Unfortunately, the new Federal Law On education in Russian Federation, which is to be implemented from 1 September 2013, does not change things dramatically. The improved definition speaks of an educational programme as "a complex of core educational elements (volume, contents, expected outcomes) and administrative and pedagogic provisions ... that is to be represented by a curriculum, an academic calendar, subject programmes, and other components, as well as assessment and methodology materials". ${ }^{6}$ Again, the need to formulate programme aims and specialisation is not mentioned directly. Only the expected outcomes are mentioned. However, if the general aim has not been considered previously, the programme will hardly reach its aim.

The Monitoring project has also identified a number of problems in the area of programme design and implementation related to drawbacks in the FSES. On the one hand, these Standards have incorporated the core categories of EHEA and TUNING (competences, learning outcomes, credits) and key methodological principles. On the other, the Standards themselves have created serious problems for the implementation of these categories by setting programme structure and outcomes requirements that were incompatible with full implementation of these methodological principles.

The major FSES drawbacks in this respect are as follows:

- The lists of generic competences proposed are not consistent among different Standards, both in terms of their number and in terms of approaches proposed even for neighbouring areas (degrees);

- The lists of subject-specific competences are excessively long in the majority of Standards and are poorly structured along the possible

${ }^{6}$ Federal Law of 29 December 2012 N 273- $\$ 3$ "On educational in the Russian Federation". 
professional activity profiles of the graduates (and in many Standards they are not grouped in any manner at all); the core subject-specific competences of every degree, obligatory for all graduates, are not set apart, which means that CEPs are obliged to cater for all the subjectspecific competences listed in the respective Standard (that are numbering from 30 to 80 for a Bachelor programme);

- The cycle (horizontal) CEP structure and cycle workloads expressed in terms of credits, as envisaged by FSES (Section 6), do not allow HEIs to design modular (vertical) elements of educational programmes and to implement the programme in the modular format associated with European Credit Transfer and Accumulation System (ECTS User's Guide $\left.(2009)^{7}\right)$.

- The learning outcomes related to particular elements of educational programmes (cycles, sections) formulated in FSES (Section 6, CEP Structure table) bear little relation to the lists of competences formulated in the same FSES (Section 5);

A solution which might be applied while waiting for the next version of the Standards (which is being currently developed by the Ministry of Education and Science of the Russian Federation) could consist of Russian HEIs incorporating the TUNING profile development methodology into their actions of designing educational programmes. As the Tuning Guide to Formulating Degree Programmes Profiles states, "The Degree Profile is a very brief document, of around two pages, designed to convey the essential information about a specific degree programme. It locates the programme in the academic map of disciplines or thematic studies. The Profile specifies the subject area or areas studied, identifies the level (first, second or third cycle) and indicates the special features that distinguish it from other similar programmes. The Degree Profile describes, in terms of competences and learning outcomes, what graduates will know, understand and be able to do by the time they have successfully completed the programme. The Profile spells out what can be expected of the graduates in terms of the kinds of tasks they are equipped to undertake, their level of expertise and the responsibilities they can assume". 8

\footnotetext{
${ }^{7}$ European Commission, ECTS Users' Guide, http://ec.europa.eu/education/pub/pdf/ higher/ectsguide_en.pdf

${ }^{8}$ Jenneke Lokhoff, Bas Wegewijs, Katja Durkin, Robert Wagenaar, Julia González, Ann Katherine Isaacs, Luigi F. Donà dalle Rose, and Mary Gobbi, eds. A Guide to Formulating Degree Programme Profiles, Competences in Education and Recognition Project (CoRe). Bilbao, Groningen, and The Hague: Universidad de Deusto, 2010, p. 15.
} 
The elements that form the profile template are as follows:

- Purpose

- Characteristics

- Employability \& further education

- Education style

- Programme competences

- List of Programme Learning Outcomes ${ }^{9}$

These elements should help educational programme designers to build a coherent whole, to make it clear to the students, instructors and potential employers how this particular degree of this particular HEI is different from other degrees within the same area of specialisation. Besides, the profile may explain how the degree in question is related to the existing national and international qualification frameworks; describe future areas of employment for the graduates; state if the degree in question is a research-oriented or an applied one, etc.

Depending on the aims and the nature of the degree, the profile enumerates the competences to be developed by the graduates, which in turn determine the desired learning outcomes. This leads to the maximum transparency of the educational process: one can clearly see why the things are done the way they are done.

The question as to which elements should build up the profile and how many elements are necessary is still being debated. There are those who believe that there should be more elements and that the profile should include, for example, a description of the degree structure, teaching and learning techniques, etc. In this case, the notion of the profile becomes every similar to that of the Russian concept of the core educational programme.

Neither approach affects the argument we have been making. In any case, this is a document (or a set of documents) developed by HEI representatives (both academic and administrative staff) and approved by relevant state bodies (by way of state accreditation) or by the society (by way of professional or public accreditation). The degree profile comes as a response to a certain demand considered relevant by society. Regardless of its size, the profile - and its Russian counterpart, CEP - should reflect an internally-coherent educational programme and explain clearly what a person who completes this programme successfully will be able to do, in what sectors he/she will be able to work and what professional activities he/ she will be able to perform.

\footnotetext{
${ }^{9}$ Ibid., 20.
} 
In spite of the fact that each educational programme is unique and reflects the points of view and decisions of the team who develop it, it should account for the key features of the relevant subject area. This is why the TUNING project has elaborated the mechanism for determining core competences, whose use could be recommended to the Russian degree designers (see below).

As predicted by the experts, Russian higher education reform has run into considerable psychological resistance within higher educational institutions against the new "meta-language" of education (competences modules - credits) and the innovative technologies of educational program development. The major difficulty here is that Russian HEIs have no experience of formulating programme's aims or mission (earlier, especially in the area of classical university education, curricula were based on traditional approaches and only rarely updated to account for advances in the relevant disciplines) or formulating measurable learning outcomes. Another major obstacle is that fact that Russian higher education degrees have traditionally provided a broad foundation rather than narrow practiceoriented professional training. What is clear is that, firstly, Russian HEIs will need considerable time if they are to truly convert to the new system, and, secondly, that forcing HEIs to apply the new format without facilitating a change in mentality can only lead to a "mechanical" - counterproductive - application of the new language.

\section{TUNING Russia}

Taking into consideration the points made above, it seems that the most reliable way of making sure the TUNING methodology is embraced widely in Russian academic circles is to clearly demonstrate the advantages provided by the TUNING basic principles and approaches. This is what the abovementioned TUNING Russia project (2010-2013) aims to achieve. The project consortium comprises $4 \mathrm{EU}$ universities (the University of Deusto (Bilbao, Spain), project Coordinator; The University of Groningen (Groningen, Netherlands); Trinity College, University of Dublin (Dublin Ireland); and University of Padua (Padua, Italy)), as well as 13 Russian HEIs (Astrakhan State University, Don State Technical University, Moscow State Academy of Business Administration, Moscow State Oblast University, Lomonosov Moscow State University, Moscow State University of Railway Engineering, N. I. Lobachevsky State University of Nizhni Novgorod, Yaroslav-the-Wise Novgorod State University, Russian State University for the Humanities, North-Caucasus State Technical University, Tver State University, Tula 
State Lev Tolstoy Pedagogical University, Udmurt State University and Association of the Classical Universities of Russia (ACUR). TUNING Russia project aims to institutionalise the use of the Tuning methodology within the educational philosophy and practice of Russian HEIs. The project has two core objectives: to create a network of TUNING consultation and methodology centres in Russia and to adapt TUNING methodological approached to the Russian system of higher education.

To reach these, working groups in the following subject areas have been created: Environmental Engineering, Foreign Languages, Information and Communication Technologies, Education, Social Work, Tourism, Ecology, Economics and Management, and Law. At the same time the project participants took into account that there was no Russian equivalent of the European notion of subject area (the existing notions were either broader or narrower than that of the subject area).

The first task addressed by the Russian and EU experts who formed the working groups was gaining first-hand practical knowledge of how to use TUNING recommendations for determining the generic and subject-specific competences for a subject area. The second task consisted in designing Reference Points that would allow development of educational programmes of all levels of higher education in each subject area (the lists of generic and subject specific competences together with generic learning outcomes for the levels of Bachelors and Masters). At the moment, the working groups are spelling out a methodology for designing educational programmes on the basis of Reference Points and are preparing pilot Bachelors and/or Masters programmes expressed in terms of modules and credits.

The lists of generic and subject-specific competences have been developed on the basis of:

- An analysis of the Russian labour market and the existing Russian professional standards for the relevant subject areas (where those exist);

- An analysis of requirements for the $1^{\text {st }}$ and $2^{\text {nd }}$ cycle CEP graduates in terms of learning outcomes, as formulated in the Russian Federation Federal State Educational Standards;

- An analysis of existing international professional standards for the relevant areas of professional activity;

- A study and adaptation of the experience of drawing up the lists of generic and subject-specific competences within EHEA;

- Consultations with Russian and European experts;

- Discussing and fine-tuning initial lists of generic competences suggested by different working groups, agreeing on the "core" 
generic competences common to all the subject area groups of the project;

- Consultations with Russian employers, students, academics and HEI graduates though written questionnaires about the provisionally proposed lists of generic and subject-specific competences prepared by working groups in each subject area.

The need to formulate a list of generic competences common for all the subject areas involved was put forth by ACUR on behalf of the Russian members of the project consortium, as one of the key steps to be completed within the TUNING Russia project. Following the steps enumerated above, such a list was created and consists of 30 competences. Next, it was important to discover which of these competences are most valued by employers and by the educational process participants. Four competences were ranked highest by all the stakeholders - employers, academics, students and graduates:

- Capacity for abstract thinking, analysis and synthesis;

- Capacity to identify, formulate and solve problems;

- Capacity for applying knowledge in practice; and

- Teamwork ability.

When the Reference Points for Educational Programmes' Design were developed for each subject area, these "core" generic competences were complemented with other generic competences from the 30-item list mentioned above. Thus, in the subject area of Economics and Management four more generic competences were added on the basis of stakeholder consultation data analysis:

- Ability to work autonomously;

- Ability to act in accordance with the principle of social responsibility and civic consciousness;

- Concern for reaching the objectives (goal-oriented approach); and

- Concern for quality (quality-oriented approach).

While determining the lists of generic competences, working groups in some subject areas decided to group these into "meta-competences". Thus, the final list of generic meta-competences for the Economics and Management subject area comprises only 7 items. When the Full common list of generic competences relevant for all Russian higher education graduates (AllRussian competences list) and the Final list of meta-competences for the area of Economics and Management were compared, it turned out that only one competence from the Full common list - project design and management - does not form part of any meta-competence of the Final list of meta- 
competences for the area of Economics and Management. All the other items of the Full common list are reflected in the Final list as parts of the seven meta-competences. This means that generic (meta-)competences particularly relevant to a specific subject area can be spelled out using the All-Russian Full common list items.

Reference Points for designing degrees of all levels developed for the subject areas addressed by the TUNING Russia project. The mechanism for moving from the general concept of a competence to the measurable learning outcomes, as well as the pilot degrees built in the modular-credit TUNING format on the basis of the Reference Points all can serve as a solid methodological basis for improving Russian higher education FSES and to help Russian HEIs develop their own educational standards.

This is why the TUNING Russia project coordinators recommend that Russian HEIs (especially those who have the right to implement educational programmes based on their own standards) to start using TUNING materials now, without waiting for FSES to be amended or replaced with a new set of Standards. It is important to understand that the TUNING methodology does not restrict programme developers in any way. The TUNING methodology preserves flexibility and autonomy, while offering a universal mechanism and a common language for formulating the degree objectives, ways of reaching these objectives (in the form of a set of learning outcomes, which, in turn, guide the formulation of the curriculum elements (modules) and the use of adequate teaching and learning techniques) and means to measure the level of competence development (descriptors).

\section{Conclusions}

Summing up, Russian HEIs are only starting to master the TUNING methodology. Thanks to the dissemination seminars and workshops organised by participants of the TEMPUS projects carried out in the early 2000s and especially by members of the current TUNING Russia (20102013) project, more and more stakeholders within the Russian higher educational system are becoming familiar with the TUNING methodology for educational programme design and with examples of best practice in TUNING-based degree design from all over Europe. Nevertheless, many of those remain passive and do not apply their knowledge of TUNING methodology when designing their own CEPs. Partly, this is due to the objective drawbacks of Russian Federal State Educational Standards and other normative documents, which adopt the competence-credit-module language but do not always explain what mechanisms can be used in order 
to implement this approach. Besides, the new mechanisms often seem foreign to those unfamiliar with them and the change of the "meta-language" may be difficult to assimilate for academics, especially for those who belong to the older generation.

In these circumstances, creating TUNING-model degree profiles may be crucial to aid the Russian HEIs in the development of the new educational programmes. Brief but all-encompassing formulation of the aims and outcomes and specific characteristics of an educational programme, listing competences and learning outcomes could permit HEIs to move from trying to comply with standards and requirements sent from above and foreign to the institutions themselves to adopting the principle of transparency and designing better and more competitive degrees.

\section{Bibliography}

Baydenko V.I. Designing federal state educational standards of higher professional education: a pilot educational program. Moscow, 2007 (Байденко В.И. Проектирование федеральных государственных образовательных стандартоввысшегопрофессиональногообразования:экспериментальная учебная авторская программа. М. 2007).

European Commission. ECTS Users' Guide. Luxemburg: European Union, 2009, 64pp. http://ec.europa.eu/education/pub/pdf/higher/ectsguide_en.pdf

KovtunY.N. Model of creating core educational programs in humanities based on TUNING-ECTS methodology for the implementation of the principles of Bologna process in Russia. History and Culturology. Chelyabinsk: Chelyabinsk State University, 2008. (Ковтун Е. Н. Модель построения основных образовательных программ по гуманитарным направлениям подготовки на основе методологии TUNING-ECTS для реализации принципов Болонского процесса 6 России. Направления подготовки ВПО «История» и «Культурология»/ Составление и научная редакция Челябинск, Челябинский государственный университет, 2008).

KovtunY.N. Results of the review of the core educational programs of HEIs, developed in accordance with the FSES: analytical report for informationalmethodological seminars for HEIs. Saratov: Saratov University Publishing House, 2012. (Ковтун Е.Н. Итоги экспертизы основных образовательных программ вузов, разработанных на базе ФГОС ВПО: аналитическая справка $\kappa$ информационно-методическим семинарам для учреждений высшего профессионального образования / автор-составитель Саратов: Издательство Саратовского университета, 2012).

Lokhoff, Jenneke, Bas Wegewijs, Katja Durkin, Robert Wagenaar, Julia González, Ann Katherine Isaacs, Luigi F. Donà dalle Rose, and Mary Gobbi, eds. A Guide to Formulating Degree Programme Profiles. Competences in Education and 
Recognition Project (CoRe), Bilbao, Groningen and The Hague: University of Deusto, 2010, 96pp.

Russian Federal Law of 10 July 1992 № 3266-I “On Education” Article 9, p.6.2. (Статья 9 п. 6.2 Закона Российской Федерации от 10 июля 1992 года № 3266- $I$ «Об образовании»).

Russian Federal Law of 22 August 1996 N 125-FZ “On higher and post-HEI professional education”, Article 5 p.5. (Статья 5 п. 5 Федерального закона от 22 августа 1996 г.N 125-Ф3 «О высшем $и$ послевузовском профессиональном образовании»).

Russian Federal Law of 29 December 2012 N 273-Ф3 “On education in the Russian Federation” Article 2 p. 5. (Федеральный закон от 29.12.2012 N 273-Ф3 «Об образовании в Российской Федерации», статья 2 п. 9)

The experience of implementing federal state educational standards by professional education institutions of the Volga federal district (Saratov, 29-30 October 2012). Materials of the seminar compiled by the Association of the Classical Universities of Russian and Saratov State University. Saratov: Saratov University Publishing House, 2012. (Опыт внедрения федеральных государственных образовательных стандартов учреждениями профессионального образования: мониторинг вузов $u$ колледжей: Материалы семинарасовещания для руководящих работников учреждений профессионального образования Приволжского федерального округа (Саратов, 29-30 октября 2012 2.). Материалы семинара-совещания подготовлены Ассоциацией классических университетов России (АКУР) совместно с Саратовским государственным университетом. Саратов: Издательство Саратовского университета), 2012). 